No. 45

JULIO DE 2017

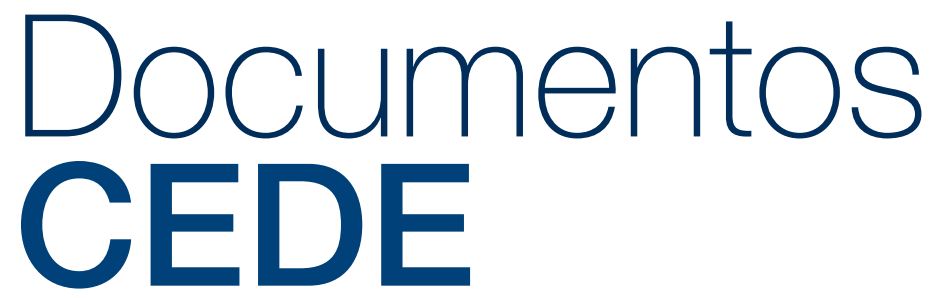

ISSN 1657-7191 Edición electrónica.

Political Economics and Possibilism: Towards an Open Notion of Development

Andrés Mauricio Guiot Isaac 


\section{CEDE}

D1)

Facultad de Economía

Serie Documentos Cede, 2017-45

ISSN 1657-7191 Edición electrónica.

Julio de 2017

(C) 2017, Universidad de los Andes, Facultad de Economía, CEDE. Calle 19A No. 1 - 37 Este, Bloque W.

Bogotá, D. C., Colombia Teléfonos: 3394949- 3394999, extensiones 2400, 2049, 2467

infocede@uniandes.edu.co

http://economia.uniandes.edu.co

Impreso en Colombia - Printed in Colombia

La serie de Documentos de Trabajo CEDE se circula con propósitos de discusión y divulgación. Los artículos no han sido evaluados por pares ni sujetos a ningún tipo de evaluación formal por parte del equipo de trabajo del CEDE.

El contenido de la presente publicación se encuentra protegido por las normas internacionales y nacionales vigentes sobre propiedad intelectual, por tanto su utilización, reproducción, comunicación pública, transformación, distribución, alquiler, préstamo público e importación, total o parcial, en todo o en parte, en formato impreso, digital o en cualquier formato conocido o por conocer, se encuentran prohibidos, y sólo serán lícitos en la medida en que se cuente con la autorización previa y expresa por escrito del autor o titular. Las limitaciones y excepciones al Derecho de Autor, sólo serán aplicables en la medida en que se den dentro de los denominados Usos Honrados (Fair use), estén previa y expresamente establecidas, no causen un grave e injustificado perjuicio a los intereses legítimos del autor o titular, y no atenten contra la normal explotación de la obra.

Universidad de los Andes | Vigilada Mineducación

Reconocimiento como Universidad: Decreto 1297 del 30 de mayo de 1964. Reconocimiento personería jurídica: Resolución 28 del 23 de febrero de 1949 Minjusticia. 


\title{
Political Economics and Possibilism: Towards an Open Notion of Development*
}

\author{
Andrés Mauricio Guiot Isaac ${ }^{* *}$
}

\begin{abstract}
Hirschman was both a pioneer and a dissenter of development economics. He shares with the high theory the virtues and misfortunes of committing to modernize the underdeveloped world, but his exposure to the politics of development in Latin America gave new life to his early insights. Revealing the political dimensions of his concepts on economic development, Hirschman provides some mini-building blocks for a political economics consistent with an open notion of development. This inquiry, however, should not be seen exclusively through a methodological lens; it is grounded on his possibilism, a claim about modernity and the possibility of change. This article reconsiders the legacy of Hirschman's thought for current debates on development and calls for recuperating his commitment to open societies.
\end{abstract}

Keywords: Hirschman, development, modernity, political economics, possibilism

JEL classification: B12, B29, B31, N46, O10

\footnotetext{
* A first draft of this article was presented in the Second History of Economics Summer School in Latin America in February 2017 and in the Annual Conference of the History of Economics Society on June 2017.

${ }^{* *}$ MA candidate in Economics, Universidad de los Andes, am.guiot699@uniandes.edu.co
} 


\section{Economía política y posibilismo: hacia una noción abierta del desarrollo* Andrés Mauricio Guiot Isaac ${ }^{* *}$}

\section{Resumen}

Hirschman fue a la vez un pionero y un disidente de la economía del desarrollo. Comparte con la alta teoría las virtudes y los infortunios del esfuerzo por modernizar el mundo subdesarrollado, pero sus intuiciones tomaron un nuevo rumbo con los acontecimientos políticos en Latinoamérica durante los años sesenta. Revelando las dimensiones políticas de sus conceptos sobre desarrollo económico, Hirschman ofrece mini-fundamentos para una economía política consistente con una noción abierta del desarrollo. Sin embargo, está investigación no es exclusivamente metodológica, pues descansa sobre su posibilismo, un juicio sobre la modernidad y la posibilidad del cambio. Este artículo considera el legado del pensamiento de Hirschman para los debates contemporáneos sobre desarrollo y aboga por recuperar su compromiso con una sociedad abierta.

Palabras clave: Hirschman, desarrollo, modernidad, economía política, posibilismo

Clasificación JEL: B12, B29, B31, N46, O10

\footnotetext{
* Un primer borrador de este artículo se presentó en la Segunda Escuela de Verano de la Asociación Latinoamericana de Historia del Pensamiento Económico en febrero del 2017 y en la Conferencia Anual de la History of Economics Society en junio del 2017.

** Candidato a grado de la Maestría en Economía, Universidad de los Andes, am.guiot699@uniandes.edu.co
} 


\section{Introduction}

In The Rise and Decline of Development Economics (1982) Albert O. Hirschman, himself both a dissenter and a pioneer of development economics ${ }^{1}$, retraces why the importance of development economics during the 1940s and 1950s faded during the 1960s and 1970s. While it attempted to become a separate field study, it ended up relegated from the center to the periphery of economics (Bardahn, 1993), discredited by both economists and other social scientists. Krugman (1993, 1994) attributed the decline of high development theory to the unwillingness and incapacity of its practitioners to formalize their ideas, Taylor (1994) charged the lack of concreteness of their policy advice, and Bardahn (1993) pointed to the underestimation of the difficulties of aggregate coordination and the undervaluation of the incentive and organizational issues of micro-management. In opposition to these methodological and practical reasons, Hirschman seems to question the central importance attributed to development economics in the first place:

"Our subdiscipline had achieved its considerable luster and excitement through the implicit idea that it could slay the dragon of backwardness virtually by itself, or, at least, that its contribution to this task was central. We now know that this is not so" (Hirschman, 2015[1982], p. 69).

Ever since, The Rise and Decline has been read as "an elegant obituary on the field" (Adelman, 2013, p. 543); the last word on a once fruitful research agenda. Amartya Sen (1983) soon questioned this dismal prospect: development economics is not dead, rather its underlying problematic was quite limited. Along these lines, Krugman (1993) and Bardahn (1993) survey some of the methodological tools and theoretical insights from high development theory that economists actually use, or may renew, without going back to old questions. Sen $(1983,2000)$ takes an alternative road and focuses on finding a broader, and more open, definition of development. Others, like Escobar (1995), assume a more critical stance towards development and look for possibilities beyond its discursive space. In any case, as Gualerzi and Sunna (2016) recently pointed out, the very definition of development is at the core of the question about decline, which means that the dispute over the concept itself remains unsettled.

\footnotetext{
${ }^{1}$ While the World Bank signaled Hirschman as one of the Pioneers of Development, he responded that he considered himself a dissenter from within the "general movement of ideas attempting to establish development economics as a new field of studies and knowledge"(Hirschman, 1984, p. 87).
} 
Under this scenario, it is profitable to dare intellectual history and ask whether the current dispute over the notion of development could benefit from Hirschman's reflections. This might seem daring because it means forcing Hirschman back to the field he once declared dead. Nevertheless, there have been some efforts in this direction. Foxley et al. (1986), Teitel (1991), and Rodwin et al. (1994) compiled a series of essays provoked by Hirschman's work as an effort of rethinking development. Bianchi (2007) provides a new reading of Hirschman's trilogy on development from a contemporary perspective, suggesting further research on the generality of his concepts. More recently, other authors have pointed out that current debates on development remain indebted to Hirschman's contributions on the role of experimentation, monitoring and evaluation in policy-making (Alacevich, 2016), on the openness of social change (Rodrik, 2007), and to his priority-oriented philosophy (Özçelik, 2014).

Other recent explorations outline that Hirschman's command of the art of trespassing from economics to politics may contribute to a more open understanding of development (Santiso, 2000, 2006; Maluf, 2015). In other words, they find in Hirschman's thought a reason for rekindling the problem of development: economics does not have to slay the dragon of backwardness by itself; it has politics. This interpretation is consistent with Cot's (2010), who considers that Hirschman's inclination for trespassing boundaries between economics and politics, to illuminate the former by means of the latter, is what gives unity to his intellectual project_-including his work on development. In the same line, Frobert and Ferranton (2003) unravel the traits of an unfinished project of political economics ${ }^{2}$ out of Hirschman's early writings in development.

While these efforts acknowledge the possibility of finding openings in Hirschman's political economics of development, they do not relate the discussion to his general reflections about modernity. Maybe Hirschman is to blame. In response to the "calamitous political consequences" of economic development in the 1960s, his "reaction was to withdraw into history, and more specifically into the history of ideas" (Hirschman, 1979, p. 62). The Passions and the Interests (1977) was the result of this withdrawal: "this essay has its origin in the incapacity of contemporary social science to shed light on the political consequences of economic growth" (Hirschman, 1977b, p. 3). However, as it turns out, his "absorption in seventeenth- and

\footnotetext{
${ }^{2}$ I will stick to Hirschman's terminology (political economics) for understanding the entanglement between economics and politics, in opposition to the expression political economy, which commonly refers to the use of economic tools and modes of analysis for understanding political phenomena. Whenever I use the expression political economy in this article, it will denote the operation of political forces on the economy.
} 
eighteenth-century thought was not entirely a matter of escaping from an unpleasant reality" (Hirschman, 1979, p. 68), but rather an effort to illuminate the political consequences of economic development with the history of ideas. Unfortunately, the relation between the political philosophy of the project of modernity and the political economy of development was mainly implicit, rather than explicit, in his writings. The failure to perceive this connection has deprived his readers from finding in his writings an understanding of development consistent with his commitment to open societies.

The purpose of this article is to enhance the importance of considering contemporary debates on development from a philosophical perspective, by making explicit this connection in Hirschman's writings. In particular, I will argue that Hirschman's political economics of development is grounded on his possibilism, a persistent attempt of widening the "limits of what is or is perceived to be possible, be it at the cost of lowering our ability, real or imaginary, to discern the probable" (Hirschman, 1971, p. 37). Moreover, I will show that possibilism is more than a methodological approach; it is a statement about modernity and the possibility of contriving self-governed change in this context. Therefore, I claim that analyzing the interactions between economics and politics in the light of the political philosophy of modernity is what allows us to find openings for development in Hirschman's thought.

In order to underpin these claims I will follow simultaneously two strategies. On the one hand, I will exploit Hirschman's participation in the criticism and subsequent appropriation of the development discourse in Latin America during the 1960s. Instead of focusing exclusively on unraveling Hirschman's political economics of development out of his early writings —as Frobert and Ferranton(2003), I will show how some of its elements reveal in the dialogue with his dissenter colleagues. On the other hand, I will take advantage of Hirschman's (1994a) acknowledged propensity to self-subversion, or the fact that he "always goes back over the same issues (...) as if he had written only one book in the course of his life" (Bianchi, 2007, p. 132; my translation). The continuous mutation of his concepts will allow me to revisit his early writings on economic development, from the perspective of his late concern with the interactions between economics and politics in the context of modernity. His propensity to selfsubversion provides me a degree of freedom that deserves a methodological note: while I allow Hirschman to clarify his early thoughts, I deny this right to his interlocutors. This may seem inappropriate — or utterly unjust — because many of them qualified some of the statements that 
I present in this writing, but it has a purpose: to locate the discussion —as Hirschman did — in the age of decline of development economics.

This article is divided into three parts. In the first two sections, I illustrate that Hirschman exploits the political dimensions of concepts that originally belonged to the domain of development economics in response to the closures entailed by two efforts for appropriating the development discourse in Latin America. While one group of authors argued that the reign of destructive passions was responsible for the condition of underdevelopment and ungovernability in the region, an alternative view blamed the uncontested victory of interests. Even if both interpretations provide openings for understanding the political economy of development, they imply closures for pursuing self-governed change. In the third chapter, I will show that Hirschman's political economics is grounded on his possibilism, a claim about modernity as an open political project. In particular, a passion for the possible emerges from the tensions of modernity that manifest openly in the problem of development.

\section{The Reign of Destructive Passions}

"The 'classical' Marxist or liberal models of development based on the experience of the more advanced countries of Europe are not applicable to Latin American conditions. The principal task in Latin America at present seems to be the construction of a theoretical model based on the experience of the last decades which can be used effectively to understand, interpret, and direct the processes of social and economic change"(Veliz, 1965, p. 8).

According to Hirschman (2015[1982]) the construct of the "typical underdeveloped country" - what other authors have called "the invention of the Third World" (Escobar, 1995), was central for both the rise and the decline of development economics. On the one hand, it gave way to the emergence of a new discursive field, because it provided a justification for the rejection of the monoeconomics claim: if "underdeveloped countries as a group are a set apart [from the advanced industrial countries] (...) [traditional economic analysis] must therefore be recast in significant respects when dealing with underdeveloped countries" (Hirschman, 2015[1982], p. 51). On the other hand, it opened a space — within the development problem — for criticisms coming from the so-called underdeveloped regions against the "easy self-confidence" (Ibid., p. 67) of ready-made solutions imported from the so-called developed regions. While the construct 
of the underdeveloped country allowed development economics to claim authority over its subject, it was subsequently used by the subject to claim exclusive authority over its own matters.

The process of appropriation of the development problem by its subject provides a propitious historical episode for rethinking the notion of development in an age of decline. As I will show in this section, a new understanding of the political economy of development in Latin America offered an interpretative opening to deal with the problems the regions faced. However, in the light of his reflections about the political project of modernity, Hirschman's scrutiny and critique of this alternative reveal that this apparent opening entails its own closures.

\subsection{The feudal-shackles thesis}

The call for a Latin American model to understand, interpret and direct the process of economic and social change that opens this section is the closing statement of the introduction to Obstacles to Change in Latin America, an anthology of essays edited by Claudio Veliz in 1965. According to the editor, notwithstanding their differences, all authors would agree that "perhaps the principal contemporary problem of Latin America" is the excessive stability of a "traditional structure (...) [that] has not only successfully resisted the impact of technological innovation, but appears to have been strengthened by it" (Veliz, 1965, p. 1). Recognizing the persistence of a traditional structure as the special characteristic of the region both justifies the call for a separate, homegrown body of knowledge, and defines its purpose: transforming this traditional structure as an imperative for social and economic change.

This rejection of the monoeconomics claim à la Latin American can be interpreted as a variation of the relative backwardness approach to development ${ }^{3}$ followed by Gerschenkron (1962) and Hirschman (1958; 1971[1965c]) to explain why European late and Latin American late-late comers followed paths of development that differed from the normative experience of England in the XIX ${ }^{\text {th }}$ century. In particular, it was considered that the persistence of a traditional structure was the manifestation of the truncated character of modernization in Latin America:

\footnotetext{
${ }^{3}$ In Economic Development: Current Research and Problem Areas, Hirschman (1958a; unpublished) locates his own work in relation to the different approaches to economic development at the time. In this survey, he presents Strategy of Economic Development (1958) as a generalization of what he calls Gerschenkron relative backwardness approach, which relates "the intensity of a country's development effort and the principal instrumentalities it is likely to use (...) to the degree of relative backwardness" (p. 7). He then argues that this approach overcomes the main defect of the Big Push approach, namely, not explaining the process by which this critical minimum effort can be generated.
} 
"[Latin America] has begun its industrial revolution without having undergone an agricultural revolution"(Chonchol, 1965, p. 81). This idea had been previously advanced by the neo-Marxist Paul Baran (1952), who argues that underdevelopment is the result of the failure of capitalism to overthrow feudal powers in former colonies, because when capitalism penetrated these countries it was already in place at a global scale. As a consequence, the so-called demonstration effect that accompanies modernization - "the process of absorption of customs, ideas, institutions, etc. originating in, or transmitted by, the developed countries"(Pinto, 1965, p. 44)— found conjunction with the aristocratic pursuit of privilege and "social prestige" (Veliz, 1965, p. 7) that characterizes traditional societies. The result is a superposition of modern and traditional rationalities, and a coalition of capitalist and feudal powers:

"Fledging bourgeoisies of the underdeveloped countries sought nothing but accommodation to the prevailing order [...] [thus] made political and economic deals with their domestic feudal overlords [...] What resulted was an economic and political amalgam combining the worst features of both worlds-feudalism and capitalism"(Baran, 1952, p. 67).

From a historical perspective, the specificity of Latin America as an underdeveloped region laid, thus, on the coexistence of traditional and modern rationalities. The resilience of land tenure patterns in the context of industrializing societies was considered the evidence of this coexistence, and the main cause for the poor economic performance of the region. In the first place, land tenure patterns were blamed for the persistence of economic inefficiencies in agricultural production: "one of the most important negative consequences of the concentration of landownership in a few hands is the inefficient use of the most abundant productive resources of agriculture in Latin America: the land and the labour force" (Chonchol, 1965, p. 83). On the one hand, given that landownership is considered a means for "social prestige, and political power", landowners have no "incentive towards improving technology or increasing capital investment, the two basic conditions for a change-over from traditional-type agriculture to modern methods" (Ibid., p. 84). On the other hand, given the unequal distribution of land, large landowners hold monopsonic power over landless peasants, which allowed them to define nonpecuniary contracts. Once again, this arrangement does not follow the logic of economic efficiency, but the logic of social and political power: "This enables the landowner to carry on the productive process without the necessity of relying on any appreciable amount of working capital, while exerting social and political power over the peasant” (Ibid.).

Besides inducing inefficiencies in agricultural production, it was perceived that the persistence of a traditional structure had perverse consequences on the process of 
industrialization. For starters, rural income inequality affects consumption patterns: while lowincome peasants are unable to consume local manufactured products (Ibid., p.79), large landowners and the fledging bourgeoisie — in the "urgent desire to imitate in their living habits the socially dominant 'old families" " — maintain a feudal style of living based on imported luxury consumption (Baran, 1952, p. 78). In this way, the unequal rural structure poises an internal and an external limit to the process of industrialization. On the one hand, domestic markets are too small for consuming local manufactured goods, and on the other, unnecessary imports drain the scarce foreign exchange reserves available for buying necessary imports. Compounding the dependence of industrialists on staple producers, this led to an "inflation-cum-overvaluation arrangement"(Hirschman, 1971[1965c], p. 128) between landowners and early industrialists that made possible the easy stages of the process ${ }^{4}$, but turned out to be the major constraint for exporting manufactures in further stages (Ibid., p. 127).

This way, the idea according to which "a number of societies that have been penetrated by capitalism are considered to be in trouble because this penetration has been too partial, timid, and halfhearted, with substantial elements of the previous social order being left intact" (Hirschman, 2015[1982], p. 231) was used to explain the alleged exhaustion of industrialization. Hirschman will come back to this feudal shackles thesis in Rival Views on Market Society (1982) to show how the ideas of The Passions and the Interests could be extended into the $\mathrm{XX}^{\text {th }}$ century (Hirschman, 1977b, p. xxii). The feudal-shackles thesis was "not a unified theory", but gathered "a series of contributions by different authors" around this "common theme" (Hirschman, 2015[1982], p. 231). Nevertheless, this thesis came at odds with the historical confidence that the Latin American ideologues of development placed on the arrival of capitalism for achieving a higher political objective: the "conquest of decision centers" (Hirschman, 1971[1961], p. 304). Social and economic change was desirable as a means for self-government. In a first wave of writings on the subject, Haya de la Torre disentangled the anti-imperialist and the anti-capitalist flag, placing hopes for political emancipation in the middle classes (Hirschman, 1971[1961], p. 277). Later on, Raúl Prebisch's manifesto trusted that Latin Americans were ready for rationalizing and commanding the imperative of industrialization through deliberate dirigisme and development planning. But what Prebisch celebrated as an opportunity for achieving self-

\footnotetext{
${ }^{4}$ Furtado's (1965) account of the process of industrialization in Brazil is illustrative: "under cover of maintaining the external price of coffee, a dual protection of industry was created, whereby the import of foreign made equivalents was virtually prohibited, and the necessary exchange made available for the import of raw materials and plant at subsidized prices".
} 
government — "the facts are imposing" industrialization (Prebisch, 1949, p. 5)—, was referred to as its "impersonal" (Pinto, 1965), and its "substitutive character" (Furtado, 1965). Along the forementioned economic setbacks, the failure of capitalism to overthrow feudal structures had devastating consequences for the pursuit of self-governance in the region: "it was now denied that (...) their bourgeoisie could ever come to play any constructive developmental role at all” (Hirschman, 2015[1982], p. 235).

The double nature of the setbacks denounced by the feudal-shackles thesis - economic inefficiencies and frustrated self-government - reveals the closeness of this view to what Hirschman (1971) considers one of the characteristic traits of his approach to development: "[thinking] in terms of development sequences in which economic and political forces interact"(p.1). Following Cot (2010), this stance constitutes the central unity of his intellectual project, which relies on the continuity from developmental concerns to the "political justifications' of market societies" (pp. 63-64; my translation) in the 1970s.

Hirschman's treatment of the feudal-shackles in Rival Views reveals that his anxieties with the political economics of development persisted in the early 1980s: “The feudal-shackles thesis thus rests on the doux-commerce thesis-without, of course, acknowledging the affiliation. It is the doux-commerce thesis in negative disguise, in critical garb, stood on its head"(Hirschman, 2015[1982], p. 232). In The Passions and the Interests, the doux-commerce thesis referred to a political argument for the expansion of commerce in the XVIII ${ }^{\text {th }}$ century, on the grounds that it would impose several constraints on the use of power by the sovereign. However, in the extension of these ideas into the $\mathrm{XX}^{\text {th }}$ century, he is concerned with the other face of the doux commerce thesis, namely, the civil political benefits of commerce: the "expected effects of commerce on the citizen and civil society" (Ibid., p. 216). Besides restraining the power of the State, commerce was expected to instill certain virtues in the citizens_ c "industriousness and assiduity, frugality, punctuality and (...) probity", nurturing the ability of civil societies "to find solutions to conflicts and a middle ground for opposed opinions" (Ibid., p. 218). Like commerce in the XVIII ${ }^{\text {th }}$ century, industrialization was expected to tame the destructive passions of underdeveloped societies in the $\mathrm{XX}^{\text {th }}$ century; it was supposed to modernize aristocratic men and traditional societies.

Once the feudal-shackles thesis is considered as the $\mathrm{XX}^{\text {th }}$ century inversion of the douxcommerce thesis, it becomes clear that for this view the persistence of a traditional structure in Latin America is more than the manifestation of the failure of capitalism: it reveals a double failure of the political project of modernization. On the one hand, this project failed to tame the 
destructive passions that characterized traditional societies. As a result, the desire for privilege and social prestige overshadowed market-oriented rationalities, contributing to the exhaustion of industrialization, and therefore threatening the process of modernization itself. On the other hand, it had failed to yield a civil society able to organize itself in an orderly manner. Furtado reveals this concern when he translates the problem of development into a problem of governance: "What particular conditions are necessary to allow development, as a supreme national objective, to prevail over class and group interests [one must say-more accordinglyimpassioned interests] in the governance of fundamental political decisions?” (Furtado, 1965, p. 145). To the regret of the ideologues of development in Latin America, it is not possible to count on the deepening of industrialization for achieving self-government: instead of yielding a doux society able to deal with its own conflicts, it resulted in a "a struggle for power between the populist leaders and the traditional ruling class (...) which tends to thwart every attempt at coherent planning” (Ibid., p. 160).

To sum up, as an attempt to appropriate the problem of development from a historical perspective, the feudal-shackles thesis resorted to a simple observation - the persistence of a traditional structure - not only for explaining the poor economic performance of the region, but also for criticizing the common pretense that industrialization would lead automatically to self-government. In the light of Hirschman's account of the decline of development economics, the feudal-shackles thesis constitutes an interpretative opening, for it takes into consideration the political consequences of economic development. Moreover, Hirschman resorted to the history of ideas to show that this interpretative opening is the result of a claim on modernity, and its double failure to tame destructive passions and to yield a civil society capable of governing itself.

\subsection{Sailing Against the Wind}

Besides providing a justification for appropriating the discourse of development, the persistence of a traditional structure in Latin America casted doubt on the possibility of pursuing selfgovernment through industrialization. Naturally, it is legitimate to ask if the interpretative opening that led to this conclusion offers an alternative road for achieving this purpose. In other words, does the political economics of development grounded on the reign of destructive passions provide an opening for actively overcoming this situation? By addressing this question, 
Hirschman was able to enlighten the political dimensions of some of his early concepts on development — some mini-building blocks for an open political economics of development.

Following Hirschman (1971[1961a]), the beginning of the 1960s experienced a shift of public attention in Latin America from integrated plans of development to land reforms. This is consistent with the political economics of the feudal-shackles thesis; if Latin Americans are concerned with the main obstacles to change in the region, the existing pattern of land tenure is among the principal obstacles. The choice of words is not neutral. Hirschman had already dealt with the language of obstacles in The Strategy of Economic Development (henceforth, The Strategy), a book conceived precisely against the propensity to produce an "ever lengthening list of factors and conditions of obstacles and prerequisites" for economic development (Hirschman, 1958b, p. 1). In particular, there was a generalized tendency among development economists to construe obstacles as abnormalities vis à vis the normative standards of economically advanced countries (Hirschman, 1971[1965b], p. 312). Instead, Hirschman proposes to understand economic development in terms of "calling forth and enlisting (...) resources and abilities that are hidden, scattered, or badly utilized" (Hirschman, 1958b, p. 5). Later on, he acknowledges his indebtedness to Keynesian economics, as the notion of idle resources and abilities is "an attempt to generalize the diagnosis of underemployment as the characteristic feature of underdevelopment" (Hirschman, 1982b, p. 56). In this sense, his major work on development can be considered part of the "high development theory" (Krugman, 1993, 1994). However, while revisiting The Strategy, Hirschman generalizes this idea beyond the semantics of investment, by arguing that it was the "search for possible bidden rationalities" which "was to give an underlying unity to my work" (Hirschman, 1984, p. 91; his emphasis). The notion of bidden rationalities implies that what a priori seem to be "shortages, bottlenecks, or unbalanced growth sequences" might have a "possible rationality ("uses') [sic]" (Ibid). This broader understanding of idle resources and abilities reveals the pitfalls of conceptualizing development in terms of obstacles and ignoring their possible uses or rationalities.

The neglect of hidden rationalities — and their potential uses for contriving change - is not, however, exclusive of high-development theorists. For the supporters of the feudal-shackles thesis, remnants of aristocratic passions impeded — through the entanglement of economic and political consequences - the conquest of decision-making centers. This obstacle raised doubts about the prospect of pursuing land reform through a political process. In fact, the failure or partial success of previous attempts is a common place at the time. Chonchol (1965) and Carroll 
(1961) consider that the success of the Mexican Revolution — the hallmark of agrarian reform in the region — was partial, because its major success — the instauration of pre-Hispanic ejidosturned out to be a major constraint for technical progress. Government incapacity endangered the success of the Bolivian Revolution, the military coup of 1954 had condemned Guatemala's agrarian reform, and the Cuban Revolution had led to government — not peasant - control of expropriated lands (Carroll, 1961). Finally, attempts short of revolution in Colombia — through legal and fiscal weapons - were considered failures due to conservative reaction and political unfeasibility (Hirschman, 1963).

Retrospectively, Hirschman (1997) acknowledged that the common perception of persistent failures to transform the agrarian structure led him to recognize the general feature about problem-solving in Latin America that he calls fracasomania: the insistence on the "utter failure [of] everything that had been done before", made Latin Americans believe that "one had to start from scratch over and over again" (Hirschman, 1975, p. 394). In the context of land tenure, this failure complex led to a normative conclusion about social change: "change is still visualized primarily as something that requires a previous revolution” (Hirschman, 1963, p.333). However, according to Hirschman, this conclusion was tautological: "revolution is always easier to visualize; for it requires 'only' violent overthrow of certain ruling groups, a head-on clash" (Hirschman, 1963, p. 168; Hirschman's emphasis). Moreover, it avoided embracing the question of social change and its paradoxical nature: "how can a society begin to move forward as it is, in spite of what it is and because of what it is" (Hirschman, 1963, p. 23). As Hirschman puts it elsewhere, if moving forward is to be the result of self-governed change, the "quest for development is also a quest for self-discovery and self-affirmation"(Hirschman, 1971[1961], p. 304). The concept of bidden rationalities comes in handy to undertake this quest, because it implies recognizing in every society "a will and intrinsic capacity for adapting, defining ends collectively and finding means to achieve them" (Frobert \& Ferranton, 2003, p.32; my translation). But fracasomanía —along with its normative conclusion - inverts this formula because it states that it is precisely what Latin American societies are and have been — traditional-passion ridden communities — which hinders the possibility of collectively deciding desirable ends and appropriate means.

By avoiding the paradoxical nature of social change, the normative conclusion that resulted from the interpretative opening of the feudal-shackles appears to be unsatisfactory for the purposes of self-government. With fracasomania and the insistence on revolution as background, Hirschman sets himself to show in Journeys Towards Progress (1963) how "change by 
methods short of revolution is or has become possible"(Hirschman, 1963, p. 333). This means delving deep into the functioning of reform, for —unlike revolution - it "requires a special combination of circumstances, a sequence of moves in the course of which the ruling groups acquiesce to, or even connive in, the nibbling away of their own privileges" (Ibid, p. 168; my emphasis). The emphasis on the sequential nature of reform over the simultaneous nature of revolution (a head-on clash) reveals Hirschman's preference for incremental gains and problem-solving strategies over total solutions for development issues (Bianchi, 2007, 142). This preference can be traced back to his theory of unbalanced growth. While balanced growth theorists advocate for a simultaneous approach — for instance, Rosenstein-Rodan's "big-push" — to attain a given desirable end, Hirschman suggests that "the economy may get faster to its goal" through chains or sequences of imbalances (Hirschman \& Lindblom, 1971[1961], p. 66) . "The crucial, but plausible, assumption here is that there is some 'slack' in the economy" (Ibid, 65). In a society with idle resources and abilities — what he will later call, more generally, hidden rationalities — sequences of unbalanced growth are dynamically more efficient than simultaneous approaches because temporal imbalances generate pressures that induce decision-makers to employ available means for attaining a desired end. Some authors have stressed on understanding Hirschman's unbalanced growth as a learning process, outlining the active role of the learner (Ellerman, 2004) and the possibility to induce further comprehension through the complementarities of learning by doing (Schön, 1994) as some of its distinctive characteristics. Along these lines, it can be argued that sequential mechanisms — like unbalanced growth, or reform - are preferable to simultaneous mechanisms - like balanced growth, or revolution - because they encourage active self-learning and maximize the understanding of the problem, contributing to the process of self-affirmation and self-discovery that characterizes development.

As I showed previously, the notion of hidden rationalities proves the futility of understanding development in terms of sociopolitical obstacles. Now the analogy between reform and unbalanced growth proves to be useful because it reveals a mechanism for exploiting these hidden rationalities for the purposes of self-governed change. In this sense, Hirschman's early insights about economic development turn out to be revealing for understanding political processes. However, once he acknowledges that economics and politics could not be disentangled, Hirschman (1984) realizes that the picture presented by the theory of unbalanced growth is rather incomplete, because it fails to take into account the conflictive nature of social decision-making: 
"to reflect the eventual all-around increases in output, the incomes received in both sectors are growing in the course of the process as a whole, but at any one point Sector A is gaining at the expense of Sector B or vice versa, making for what might be called an antagonistic growth process" (p. 106).

Even if we allow that the process of development yields overall progress, at any point the gain of one sector (social class, interest group, etc.) may result in a loss for other sectors ${ }^{5}$. This is how the feudal-shackles thesis portrayed the problem of agrarian reform: even if it appears to be a straightforward solution for both economic stagnation and political heteronomy, it keeps finding impassioned reaction from traditional powers. While the call for revolution —as a head-on clashis a direct response to the antagonistic character of social decision-making, the sequential character of reform imposes further restrictions: the ruling groups must be accomplices in the nibbling away of their own privileges. This requirement is coherent with the paradoxical nature of change and the notion of hidden rationalities: if society is to move forward, as it is, in spite of what it is and because of what it is, and feudal-type passions are considered a distinctive character of what it is, self-governed change requires looking some place for them in the process. In $A$ Dissenter's Confession, Hirschman will argue that, in the midst of antagonistic conflicts, democratic societies move forward like if they were "sailing against the wind" (Ibid. p.108).

The apparent success of agrarian reform in Colombia provided Hirschman with a case study for what only twenty years later he will call sailing against the wind. As mentioned earlier, attempts for transforming rural structures through reform in Latin America were considered utter failures. Colombia was not the exception. Both legal and fiscal weapons were unsuccessful in the face of conservatory reaction. However, Carlos Lleras Restrepo managed to break the pattern by promoting Law 135 of 1961, which imposed enforceable conditions for expropriating land in function of its productivity. In this way, the question about the possibility of selfgoverned change under adverse political-economic conditions found expression in a concrete case: how was Law 135 of 1961 even possible?

Paradoxically, Hirschman points to the "energizing function”(Hirschman, 1963, p. 321) of fracasomania: "[previous failures] had prepared the intellectual climate for the acceptance of direct land distribution as the only effective measure"(Ibid., p. 210). After Law 200 of 1936 failed to succeed in transforming land tenure patterns, there was a general agreement that legal weapons were an inappropriate mean for that end. Moreover, land redistribution stopped being

\footnotetext{
${ }^{5}$ Recent literature on the relation between institutions and development has stressed that society may reach inefficient equilibria when de facto powers have political interests in preserving these inefficiencies. See, for example, Acemoglu \& Robinson (2006)
} 
perceived as an attainable end and ceded its place to "the need for increasing the food supply and for making more rational use of the available land resources" (Ibid., p. 160). This led the Currie Mission in 1949 to place the emphasis on fiscal weapons, proposing land taxes to penalize underutilization. In turn, its technical implausibility —as a manifestation of political opposition — showed its inadequacy as a mean, but also rekindled interest in land redistribution as a valuable end under new circumstances.

The way in which this sequence of decision-making unfolds reveals something about the learning process involved: the desirability of ends is not independent from the plausibility of means. As Hirschman reveals while stating the points of convergence between his thought and Lindblom's Science of Muddling Through, means and ends are inseparable in rational decisionmaking processes: "in rational problem solving, goals will change not only in detail but in a more fundamental sense through experience with a succession of means-ends and ends-means adjustments"(Hirschman \& Lindblom, 1971[1961], p.76). Lindblom and Hirschman agree that goals cannot be set from the onset, without an empirical evaluation of means. For ends to be valuable, they must show to be attainable, which implies that decision-makers must be able to discern possible means for pursuing them. If no means appear to be available, decision-makers may learn that perhaps it is not a desirable end. Conversely, pursuing a specific end may reveal possible means, previously ignored. In short, learning about means induces new learnings about ends and vice versa. In that sense, instead of fixing desirable ends a priori, and deliberating about adequate means a posteriori, decision-makers "muddle through" a succession of means-ends and endmeans adjustments.

Formally, allowing for means-ends adjustments in decision-making may contribute to explain the process of change that Hirschman coined sailing against the wind. In particular, an antagonistic conflict between two parties that pursue contradictory ends may be perceived as non-antagonistic under new circumstances. According to Hirschman, two seemingly external circumstances contributed to the shift of perception towards land redistribution in Colombia: (1) "social unrest in the countryside resulting from living conditions", and (2) "inflationary pressures and balance-of-payments deficits" as a consequence of "low agricultural production and productivity" (Hirschman, 1965a, p. 209). Nevertheless, these apparently external circumstances stemmed from what was considered the characteristic trait of Latin American

\footnotetext{
${ }^{6}$ Hirschman (1984) relates his understanding of rationality to Simon's (1955) work on “"satisficing' as opposed to 'maximizing"'(p. 95).
} 
societies: the reign of destructive passions. As I showed previously, it was perceived that the search for reputation as primum mobile yielded inefficient land tenure and consumption patterns, which were accounted responsible for both low living conditions in rural areas and the exhaustion of industrialization. In the first place, this implied that the modernization of the cities was truncated, therefore migration — what Hirschman will later call exit — was no longer the best response for poor peasants, who opted to stay and fight for better living conditions in the countryside-what Hirschman will later call voice ${ }^{8}$. In the second place, with the resulting exbaustion of industrialization, the inflation-cum-overvaluation pact stopped being beneficial for local industrialists, who "cannot always be counted on to stand up in public for their backward, semi-feudal brethren” (Hirschman, 1963, p. 209).

Finally, in the light of past failures, the political-economic consequences of feudal shackles acquired significance for the social readjustment of means and ends that made possible the enactment of Law 135 of 1961. On the one hand, landless peasants and industrialists raised their voices for solving the problems generated by rural inefficiencies, and as land taxes had proven to be an inappropriate mean, redistribution became again a desirable end for them. On the other hand, as previous legal attempts had proven to be unsuccessful, traditional powers dismissed them as an inadequate mean to achieve redistribution, just to "find out too late that they have started up a machine which they cannot control"(Hirschman, 1963, p. 211). Unwittingly, traditional powers ended up participating in a "revolution by stealth" (Ibid., p. 213), as accomplices of the nibbling away of their own privileges.

To sum up, Hirschman found in the Colombian agrarian reform of 1961 a case study for showing that governed change was possible, even under adverse sociopolitical circumstances. But, more generally, this specific case study reveals how processes of social decision-making can be effective for dealing with antagonistic conflicts and entrenched powerful parties. The political economics of the feudal-shackles thesis was incapable of showing how self-governed change was possible under these circumstances; but it also failed to demonstrate its impossibility. Sailing against the wind, a social learning process grounded on the notion of hidden rationalities, is

\footnotetext{
${ }^{7}$ See Exit, Voice, and Loyalty.

8 Following these lines, Hirschman criticized Currie's overconfidence on modernization in Operación Colombia: "since, so he argued, the hilly and mountainous parts of the country could never provide a decent living to those who work them and since the flatlands are best organized as large-scale mechanized farm unites, Colombia peasants really have nowhere to go but the cities(...) [but], the picture painted by Currie of Colombia’s agriculture was much overdrawn”(Hirschman, 1963, p. 207)
} 
Hirschman's response to the pretense that traditional passions are destructive enough for impeding the development of self-governed societies.

\section{The uncontested reign of interests}

As early as Obstacles to change in Latin America was published, the feudal-shackles thesis was criticized from within. Sunkel wrote that there was a tendency to "oversimplify the analysis" and to "produce an exaggerated interest in the obstacles to social change", while "traditional" societies had "shown great flexibility in absorbing elements of modernization" (Sunkel, 1965, p. 117). Sunkel's article sows doubts on the failure of modernity to tame feudal passions, but not on its ability to accomplish what it was expected to: "after almost three decades $(. .$.$) there is no$ clear indication that the process of social change has in fact produced the expected results"(Ibid., p. 117).

If the feudal-shackles thesis was ungrounded, a new body of knowledge was necessary to answer, without blaming destructive passions, why the performance of capitalism in the region was beneath its expectations. Two related alternatives - the thesis of the development of underdevelopment and the dependency thesis - would attempt to fill this need, pointing to the uncontested triumph of interests in the region. Nevertheless, Hirschman shows that, despite providing interpretative openings, these alternative attempts of appropriating the development discourse entail their own closures.

\subsection{The thesis of the development of underdevelopment}

Sunkel's concern about the underestimation of the transforming power of modernization in the region was soon taken to its last consequences. Gunder Frank argued that "references to an autarchic, closed, recluse, feudal, subsistence economy misrepresent the reality of Chile and Latin America since the sixteenth-century conquest", thus, "underdevelopment cannot be attributed to the supposed partial survival of a feudal structure, which never existed there in whole or in part” (Gunder-Frank, 1967, pp. 5, 115). On the contrary, "underdevelopment (...)

[in Latin America] is the necessary product of four centuries of capitalist development and of the internal contradictions of capitalism itself' (Ibid., p. 3). In other words, it is the historical 
absence of a traditional structure — not its persistency, and the early triumph of capitalism not its late defeat - what justifies the rejection of the monoeconomics claim.

Therefore, underdeveloped countries need to develop "theory and analysis adequate to encompass the structure and development of capitalist system on an integrated world scale and to explain its contradictory development which generates at once, economic development and underdevelopment on international, national, local and sectoral levels” (Ibid, p. xv). Once again, "the theoretical categories which were developed on the basis of the experience with the classical development of capitalism in the metropolitan countries alone are not adequate to this task [...] It will be necessary instead [...] to develop a realistic political economy of growth in the underdeveloped part of the world" (Ibid., pp. 15-16). The rejection of the feudal shackles thesis left a blank space, and with it the promise of a new opening for the subjects of development to express their voice on their own matters.

The thesis of the development of underdevelopment was contrived to fill the blank. It is premised in three propositions. In the first place, the expansion of the capitalist system is characterized by a deepening global polarization between metropolitan centers and peripheral satellites. In the second place, the penetration of capitalism assigned asymmetrical positions and functions to metropolis and satellites, which allow the former to profit from monopolistic structures to appropriate the economic surplus of the latter. Finally, this asymmetric structure recreates and reproduces itself within the satellites (creating metropolis-satellite microstructures) and throughout different stages of development. The conclusion: the underdevelopment of the satellites is the necessary counterpart of the development of the metropolis.

This mechanism of polarization, appropriation and reproduction is the theoretical basis for understanding the political economics of the development of underdevelopment. In Gunder Frank's schema, the central characteristic of central economies is their monopolistic position regarding peripheral economies. Besides allowing central economies to extract economic surplus, this monopolist structure deepens the underdevelopment of the peripheries, because it leads to the "misdirection and misuse even of the surplus that does remain available to the satellite" (Ibid., p. 28). Now, this economic self-feeding asymmetry strengthens the metropolis as the locus of decision-making, because local powers are interested in reproducing this situation within the satellites. As satellite powers have vested interests on extracting surplus from their respective peripheries, they comply with subordinating the common interest of the satellite to the interests of the metropolis: 
"there can be no hope of a bourgeoisie leading the economy and people out of underdevelopment $(\ldots)$ [its potential is limited] by its own created and vested interest in maintaining this capitalist structure on the world, national, provincial and local level in alliance with other bourgeois vested interest groups" (Ibid., pp. 118119).

In the previous chapter, I showed how the feudal-shackles thesis arrived to a similar conclusion: local bourgeoisies could not be trusted for achieving self-government in the region. However, for the thesis of the development of underdevelopment, the reason was not that the penetration of capitalism had been too timid, or partial, and therefore unable to install marketoriented rationalities in the region. On the contrary, satellite powers complied with the transfer of decision-making centers to the metropolis precisely because capitalism had triumphed in the region from the onset:

"Domestic power has always been in the hands of a bourgeoisie which was and is intimately tied to foreign interests, was and is primarily commercial, and did and does appropriate economic surplus from all the important sectors of the economy" (Gunder-Frank, 1967, p. 116; my emphasis)

Given the absence of feudal rationalities, the penetration of capitalism was uncontested in regions like Latin America. This means that vested interests of domestic powers are not the explanantia, but the explananda: they respond to a logic of subordination embedded in the rationale of an ever-expanding capitalism. While, in their specificity, local and foreign interests may change, the relation of subordination is governed by the same logic. In the words of Gunder Frank, underdevelopment must be understood "in the context of this capitalist contradiction of continuity in change"(Gunder-Frank, 1967, p. 117).

While the political economics of the feudal-shackles thesis is grounded on the reign of destructive passions, the political economics of the thesis of the development of underdevelopment is the result of an immutable logic of subordinated interests. Nevertheless, this conclusion came at odds with one of the major intellectual accomplishments of the political project of modernity: finding an economic justification for the doctrine of interests. Following Hirschman (1977b), Adam Smith made the crucial move when he equated the passions with the interests, "by holding that ambition, the lust for power, and the desire for respect can all be satisfied by economic improvement" (p. 110). This semantic identification gave way to the "idea that the material welfare of the 'whole society' is advanced when everyone is allowed to follow his own private interest” (Ibid., p. 111). However, in Gunder Frank's schema, feudal passions — the lust for power and the desire for respect- were inexistent in the satellites, even when they were prevalent in the metropolis. Therefore, while bourgeois interests were in struggle with 
feudal passions in the metropolis, they were victorious in the satellites by default ${ }^{9}$. But the uncontested penetration of capitalism in the peripheries should be understood in the light of the struggle for power in the center: bourgeois interests in the satellites are just instrumental to the legitimation of metropolitan bourgeois interests as the most appropriate means for satisfying the desire for power ${ }^{10}$. As a result, letting everyone follow their own private interest does not lead to material welfare for the whole society, but to the development of the metropolis at the expense of the underdevelopment of the satellites.

To sum up, the denial of the feudal-shackles thesis demanded a new justification for rejecting the monoeconomics claim so that underdevelopment could be explained from within. The thesis of the development of underdevelopment provided this justification by exposing the entanglement of economic and political consequences that resulted from the rapid expansion of capitalism and the uncontested triumph of interests in the peripheral satellites. Once again, this interpretative opening was grounded on a claim about modernity, namely, that domestic interests in underdeveloped societies are tied to foreign ones following an immutable logic of subordination.

\subsection{Micro-marxism}

In A Generalized Linkage Approach to Development (1977), Hirschman recognized the interpretative opening of Gunder Frank's thesis:

"One of the great merits of the development-of-underdevelopment thesis has been the devastating and definitive critique of the concept of 'traditional society', an unhistorical construct endemic in much of the previous development literature, that supposedly prevailed wherever dynamic development had not yet taken hold"(Hirschman, 1977a, p. 180).

\footnotetext{
${ }^{9}$ In Rival Views of Market Society, Hirschman presents a similar statement when he assesses the arguments for what he calls "the feudal-blessings thesis", as opposed to the feudal-shackles thesis. He argues that persistent feudal structures may be beneficial for subsequent capitalist development because built-on conflicts that characterize these societies guarantee enough diversity to counteract the "tyranny of the majority"(Hirschman, 2015[1982], p. 238).

${ }^{10}$ Hirschman (1981[1976]) relates ECLA's thesis about the "structural stagnation" of industrialization to some theses of imperialism that can be ascribed to Hobson and Luxemburg, but could be traced back to Hegel's Philosophy of Right. Gunder Frank's thesis can also be related to this literature, as he seems to suggest that colonization was the result of the expansion of capitalism in order to avoid its decline.
} 
However, for the matters of conquering decision-making centers, Gunder Frank's alternative to the concept of traditional society, the capitalist contradiction of continuity in change was equally disappointing:

"It is too bad that some of the critics have substituted for this construct the unhistorical notion of a uniform downward slide which all countries outside the capitalist-imperialist center are supposed to have experienced or to be experiencing until such time as they throw off the imperialist or neo-imperialist yoke" (Ibid)

As an alternative, Hirschman proposed a generalized linkage approach to development, which besides being "equally able to account for the lack of development or for periods of development of underdevelopment $(. .$.$) has a claim to being more truly dialectical than the development of$ underdevelopment thesis" (Ibid., p 179-180).

In The Strategy, Hirschman (1958b) introduces linkages as mechanisms for inducing “investment decisions" within "directly productive activities themselves"(p. 98). In particular, he identifies two mechanisms: some economic activities "will induce attempts to supply through domestic production the inputs needed in that activity [backward linkages]" or "will induce attempts to utilize its outputs as inputs in some new activities [forward linkages]" (Ibid., 100). Against the reading of Little (1982), Krugman (1993) considers that Hirschman's linkages can be interpreted exclusively in terms of "pecuniary externalities linked to economic scale" (p. 23), suggesting that his "distinctive contribution — from the rest of the high-development theorists - is more one of style than of substance" (Ibid., 25). Revisiting the notion of linkages, Hirschman (1986a) clarifies that when he introduced the concept, he was more concerned with the creation of new productive activities, than with the expansion of existing ones. This reflection leads Ocampo (2008) to highlight that Hirschman's concept was "more dynamic than static", privileging "sequential over simultaneous solutions to the problem of development" (p. 49, 50; my translation). In the previous chapter, I showed how a sequential approach to reform permitted exploiting hidden rationalities for the purposes of decision-making, through learning processes that involved readjustments of both means and ends. In this section, I will argue that linkages should be understood broadly as mechanisms for eliciting decentralized learning through social conflicts, and not just investment decisions through pecuniary incentives.

As Hirschman $(1984,1986 a)$ has repeatedly recognized, the notion of linkages was originally conceived to account for the characteristic inducement mechanisms of the secondary 
sector: agriculture was not supposed to induce further activities. Nevertheless, the staple theory ${ }^{11}$ uses this concept to explain how primary exports can promote economic growth through its own inducement mechanisms. For one, this theory outlines that - besides backward and forward linkages — staples can generate "final demand linkages", understood as "the measure of the inducement to invest in domestic industries producing consumer goods for factors in the export sector"(Watkins, 1963, p. 145). In other words, when a country depends strongly on the primary exports sector, staple productions may induce investments in other sectors through its impact on the size and functioning of the domestic market. Furthermore, Hirschman (2015[1977a]) adds that staple economies can have "fiscal linkage" effects, through "the ability of the state to tap the income stream accruing from the staple to various parties"(p. 162). Therefore, besides having effects on the size and functioning of the market, staples may have effects on the size and functioning of the state.

By considering the potential uses of agriculture for the purposes of development, Hirschman widened the scope of the concept beyond backward and forward linkages, generalizing the insight developed in Strategy to "constellations of linkages"(Hirschman, 1984, p. 98) ${ }^{12}$. Nevertheless, the generality of this approach does not accrue exclusively from augmenting the number of linkages; it derives from the qualitative consequences of their interactions. By definition, backward and forward linkages are complementary: if one of the mechanisms is at work, triggering the remaining one just accelerates the process. Under the narrow approach, economic growth — and, more generally, decision-making — advances smoothly. However, once one acknowledges the existence of final demand and fiscal linkages, the outcome of this interplay of forces turns less predictable, because "one kind of linkage is often to be had only at the expense of another" (Hirschman, 2015[1977a], p. 162). This means taking into account that linkage effects may be a source of conflicts; at some point, one sector may grow at expense of the other one in an antagonistic fashion, like sailing against the wind processes. But the new linkage approach becomes an appropriate tool for understanding decentralized interactions between economics and politics that go beyond the space of policy-making: "this approach almost

\footnotetext{
${ }^{11}$ Watkins (1963) characterizes the staple theory as follows: "The fundamental assumption of the staple theory is that the staple exports are the leading sector of the economy and set the pace for economic growth (...) Economic development would be a process of diversification around the export base. The central concept of the staple theory, therefore, is the spread effects of the export sector, that is, the impact of export activity on domestic economy and society" (p. 143).

${ }^{12}$ Evans (1986) broadens the application of linkages to advanced industrial sectors, and adds another type of linkage to the list: "managerial linkages".
} 
compels one to consider the interaction between the social structure and the state, on one hand, and the more narrowly economic factors, on the other"(Hirschman, 2015[1977a], p. 98; my emphasis).

While the simplified linkage approach ignores that technologies of production involved political outcomes, the generalized linkage approach provides an opening for dealing with them. In particular, it allows Hirschman to account for cases in which development has dismal results. Just after publishing The Passions and the Interests, Hirschman (1979) maintained that one of the reasons for the disenchantment with development economics in Latin America was its incapacity to foresee the calamitous political consequences of economic development. In his comment to A Dissenter's Confession, Paul Streeten (1984) argued that Hirschman himself tended to ignore the excesses of his own theory on inducement mechanisms. Nevertheless, long before these (self)critique(s), his generalized linkage approach provided some tools for explaining the dismal political consequences of development within the framework of inducement mechanisms.

Take, for instance, the case of Chile in the XIX ${ }^{\text {th }}$ century: why was the result of exporting nitrates a situation of deepened underdevelopment and domination, and not the diversification of the economy and the conquest of decision-making centers? According to Gunder Frank, one should point to the dynamics of reproduction of capitalist structures within Chile: the only tie between the central region, as metropolis within the satellite, and the mining states of the northern Chile, as satellites within the satellite, was a relation of surplus extraction and political domination. Hirschman offers an alternative explanation in terms of the technological properties of enclave economies: "the enclave is defined by the absences of involvement with the rest of the economy, that is, by the absence of other kinds of linkages" (Hirschman, 2015[1977a], p. 162). When staples consolidate as enclave economies, the absence of backward, forward and final demand linkages explains the condition of underdevelopment that surrounds them. In certain cases, however, these absences enable the appearance of fiscal linkages: "being a foreign body, owned by foreigners to boot, the enclave has few defenders of its interests” (Ibid.), which eases the task of levying taxes. Nevertheless, this result has its counterpart: when the enclave involves vocal interests - for instance, an alliance between local and foreign interests - fiscal linkages tend to be poor or inexistent. Moreover, this apparent advantage may turn out to be a curse in disguise because it may promote rent seeking: "the possibility of either faulty investment [of tax revenue] or a great leakage on the way-for example, the siphoned-off funds may simply lead to an enlarged bureaucracy" (Ibid., p. 164). As a result, besides emerging in the absence of production and final demand linkages, fiscal linkages may worsen the condition of 
underdevelopment by augmenting the stakes of domestic elites in the staple, and hence compounding their subordination to metropolitan interests.

By acknowledging that the interaction between different types of linkages may lead to conflicts of interests, Hirschman manages to account for the pervasive political consequences of the development of underdevelopment thesis. But the political economics of the generalized linkage approach also allows for other possibilities. For instance, instead of developing an enclave economy, coffee exports in Brazil and Colombia have "been crucial to the creation of settlement patterns, transportation networks and consumption linkages" (Ibid., p. 163). How to explain that seemingly identical technologies — nitrates and coffee as staples — led to such divergent results? While in a macro-level nitrate and coffee can be simply considered as staples, in a micro-level they defer in what Hirschman calls their "technological 'strangeness"” (Ibid., p. 166) to new economic activities. In The Strategy, Hirschman deals with the economic consequences of technological differences in a micro-level when he argues that machine-paced operations are less exposed to inefficiencies than operator-paced activities because they require periodic maintenance. Afterwards, in Development Projects Observed (1967), he relates this insight to the notion of latitude in standards of performance: high-maintenance activities exhibit poor tolerance for bad performance, therefore, they exert strong pressures for efficiency. However, the technological strangeness is higher between narrow-latitude activities — such as high-tech operations - and wide-latitude activities — such as staples. This means that processes that exhibit high technological strangeness to other activities generate stronger forward linkage effects, but demand a higher amount of learning on the producer if he is planning to take the technological leap himself. This is the case of nitrate processing operations, which, given the "compelling requirements of the staple's export technology, tend to be undertaken and controlled by groups distinct from the grower [producer] of the staple" (Hirschman, 2015[1977a], p. 168) — for instance, foreign companies. In turn, processing, transporting and commercializing coffee requires a minimum of learning from the grower: "he or a member of his family may become specialized in these functions; and from a strong base here he can eventually contribute to industrial development through the exploitation of opportunities for consumption linkages" (Ibid.)

Moreover, subtle technological differences yield great divergences in the interplay of political forces that surround the staple. Given their stakes on weak fiscal linkages, Chilean elites subjected their interests to foreign powers, while in Brazil and Colombia, not only coffee growers 
were nationals, but also strong and vocal pressure groups. In fact, precisely because coffee was crucial to the creation of consumption linkages, it "yielded a fiscal contribution only quite late in its history" (Ibid., p. 163). The wide latitude of processing, transporting and commercializing coffee allowed coffee growers to learn how to perform these activities, but also to expand their influence by building "intimate ties to a dense network of traders and townspeople" (Ibid., p. 162). In turn, this network of regional interests plays against the prospects of extracting surplus through fiscal linkages: "Clearly, with so many friends in court this activity is not likely to be subjected to significant special taxation" (Ibid.) ${ }^{13}$.

While for Gunder Frank staple exports inevitably lead to the development of underdevelopment, Hirschman's generalized linkage approach reveals other possibilities: small technological differences may result in a complex interplay of economic and political forces. In his effort to "trace influences that go from the product and its technology-that is, from the 'productive forces' to a specific shape of economic development and to certain sociopolitical happenings" (Ibid., p. 181), Hirschman's political economics resembles Gunder Frank's. However, the former defers from the latter in the nature and direction of these influences: rather than following a univocal path — a capitalist contradiction of continuity in change - they are multiple, follow conflictive behaviors and lead to different sociopolitical outcomes. Hirschman's approach is more truly dialectical because his understanding of conflicts breaks into pieces the determinacy of interests:

"[While] Marxist thought has traditionally focused on a very few constellation of productive forces $(. .$.$) [and] social and political configurations are seen as deriving$ from these macromodes $(. .$.$) [the generalized linkage approach] does so on a much$ smaller scale, in much more minute detail, and for a much more limited time frame. Hence, 'micro-Marxism' might be a good term for this attempt" (Hirschman, 2015[1977a], p. 181)

Micro-Marxism —analyzing the relationship between economics and politics in a small scale- is Hirschman's response to Gunder Frank's attempt to condemn asymmetrical, antagonistic conflicts to an iron law of inertia. This fragmentation of conflicts ${ }^{14}$ loosens up the tight logic of subordination that results from an early victory of capitalism in the peripheries. However, as I will show in the next sub-section, it is necessary to take the analysis one step

\footnotetext{
${ }^{13}$ In $A$ Dissenter's Confession, Hirschman relates wide-latitude to exit and narrow- latitude to voice. In the case of coffee producers, however, wide latitude strengthened, not weakened, their voice as a group.

${ }^{14}$ Beyond the dilemma between antagonistic and non-antagonistic conflicts, Hirschman (1994b) will argue that divisible conflicts, those susceptible of negotiation and bargaining, are the glue that keeps together democratic market societies, while either-or conflicts tear societies apart.
} 
forward in order to free the political economics of development from this closed doctrine of interests.

\subsection{The thesis of dependency}

While the thesis of the development of underdevelopment had the merit of being a devastating and definitive critique of the concept of the unhistorical construct of 'traditional society', it restricted change to an immutable logic of continuity, which disavowed that - in a smaller scale- conflicts of interests can take divergent paths. A related body of knowledge accepted the rejection of the feudal shackles thesis, and the fact that "underdevelopment and development are two faces of the same universal historical process” (Sunkel \& Paz, 1970, p. 37; my translation), but opposed every "mechanic-causal" approach that "outlines one previous, external determination which produces subsequent, internal 'consequences"' (Cardoso \& Faletto, 1969, p. 20; my translation). Instead, it proposed to understand this determination as a historical process in which "the tensions between groups with divergent interests and orientations find a filter by which merely economic influxes would find their way" (Ibid., p. 19). In other words, this stance embraced the comprehension of the political economics of development in terms of conflicting interests, but looked for possibilities beyond a determinate relationship between the internal and the external sphere.

In order to find "the nexus and dynamics of the different aspects and levels of reality that affect the possibilities of development" (Ibid., p. 21), this interpretative turn demands a new way of thinking the points of juncture between economics and politics. To start with, conventional dichotomies — such as underdeveloped-developed, and center-periphery- are inappropriate for this task. On the one hand, "the notion of underdevelopment characterizes a state or degree of differentiation of the productive structure (...) without emphasizing the patterns of control of production and consumption decisions" (Ibid., p. 25). While the concept of underdevelopment may account for the mechanics of production and consumption, it fails to understand that they are the result of decision-making processes in a context of antagonistic conflicts. On the other hand, "the notions of 'center' and 'periphery' (...) highlight the functions fulfilled by underdeveloped economies in the global market, without stressing at all on the sociopolitical aspects implied in the situation of dependency"(Ibid.). The dichotomy center-

periphery — and equivalently the dichotomy metropolis-satellite- captures the fact that the 
process of integration to global markets assigns asymmetrical positions and functions to different societies, but fails to account for the "mode by which this integration was historically achieved"(Ibid, p.26). Consequently, it is inappropriate for explaining the relation between the process of integration to global markets and the locus of decision-making within a given society. The criticism of conventional dichotomies reveals that for these authors an open political economics of development should account for the interlaces between economic relations and the locus of decision-making within a society, but should also be able to explain its asymmetrical nature, without taking it for granted.

Along these lines, this body of knowledge proposes replacing using the notion of dependency as the conceptual foundation for a political economics of development. Unlike developed-underdeveloped, and center-periphery, the dichotomy autonomy-dependency alludes directly to the fact that "the way national economies integrate international markets supposes definite and distinct forms of interrelation between social groups in the country, both within them and with external groups" (Ibid., p. 28). Even so, this semantic convenience requires a clarification: "it is necessary to have into account that there is no immediate connection between the distinctiveness of the economic system and the formation of autonomous decision centers" (Ibid., p. 25). In this sense, this approach is closer to Hirschman's micro-Marxism, because it breaks the correspondence between modes (technologies) of production and socio-economic outcomes, focusing instead on particular and historically determined modes of interaction. In this way, the dependency thesis offers an interpretative opening for analyzing the interaction between economics and politics in a smaller scale.

Still, this new interpretative turn seems to leave few possibilities for self-governed change. While the notion of dependency manages to break with the "belief of a mechanic conditioning of the internal (or national) socio-political situation by foreign domination" (Ibid., p. 162), it alludes to the existence of "structural bonds that limit the possibilities of action" (Ibid., p. 163). Moreover, even if these limiting structural bonds are historically determined, they are still considered to be the result of asymmetrical economic relations. For instance, the objective conditions defined by the "external market" (Ibid, p. 29) were replaced by "a new type of dependency" characterized by the "internationalization of the internal market" (Ibid., pp. 149, 147). Therefore, even if this new doctrine of interests loosens up the external conditionings for self-governed decision-making, it restricts the scope of action to the limits of some structural bonds. Once again, an interpretative opening results in a pragmatic closure. 


\subsection{Beyond Asymmetry}

In 1976, Hirschman was invited to a conference organized by LASA, called Dependency Theory Reassessed. As chairman of the conference, Hirschman introduced himself as the "Founding Grandfather of dependencia" for advancing the main ideas of the dependency thesis way before it was conceived by its fathers ${ }^{15}$. In the National Power and the Structure of Foreign Trade (1945), he stressed that commerce could be used as an instrument to exert political influence over other nations: "this relationship could work as a modern application of the old sentence fortuna est servitus"(Hirschman, 1945, p. 18). This conclusion resulted from a paradoxical aspect of international commerce: whenever gains from trade are subjectively greater for one nation, it becomes more dependent on its trading partners ${ }^{16}$. In the same line of the theses considered in this chapter, young Hirschman maintains that this dependency results from an initial asymmetry of power: "the adoption of certain economic policies that lead to augment the power for a given nation is solely possible if it exists an initial disequilibrium of power in favor of this nation"(Hirschman, 1945, p. 14). According to young Hirschman, international commerce just provided the mechanisms for reproducing and expanding these initial asymmetries of power.

Nevertheless, thirty years later, old Hirschman asks young Hirschman: "how solid or stable is the resulting relation of domination and dependency?"(Hirschman, 1978, p.47). Is it not possible to find "a slightly more reliable relation between the initial asymmetry and some builtin tendency towards its elimination or reduction"? (Ibid.). Like himself as a young man, dependency theorists ignored the possibility of finding counterforces within the mechanism of domination through commerce:

"they too tend to rest content with the demonstration that dependency relations are deeply entrenched in the structure of international system; they hardly ever explored whether that system might contain the 'seeds of its own destruction' or might otherwise be subject to some changes”(Hirschman, 1978, p. 47)

\footnotetext{
${ }^{15}$ Development Theory Reassessed: LASA meeting 1976 in "Beyond Asymmetry: Critical Notes on Myself as a Young Man and on Some Other Old Friends"; 1971-1979; Albert O. Hirschman Papers, Box 9, Folder 14; Public Policy Papers, Department of Rare Books and Special Collections, Princeton University Library.

${ }^{16}$ In particular, a nation is enslaved to its fortune when, "after being rather elastic for small quantities of merchandises from the other nation, [its demand for foreign merchandises] turns out to be inelastic in the last (and most important) parts"(Hirschman, 1945, p. 25) (Hirschman, 1945a, p. 25). This import inelasticity confers a monopolistic position to the trader partners that export its most cherished needs. Moreover, young Hirschman recognized that this "inherent weakness" (Ibid) of the commercial system was compounded by its effects on the national political arena through the creation of "influence groups that exhibit greater interest in maintaining and expanding commerce in certain sectors than in the whole country" (Ibid., p. 32).
} 
In the previous chapter, I showed how self-governed change demanded from society to move forward as it is, in spite of what it is and because of what it is. In the end, the persistence of feudal passions - the distinctive characteristic of Latin American societies - proved to be the seed of its own destruction. In a similar gesture, Hirschman (1978) argues that power asymmetries understood in terms of foreign control of local interests - generate an asymmetry in attention that favors the dependent country:

"A country whose trade or investment is dominated by ties into a large and rich country is, at some point, likely to devote its attention with single-minded concentration to this uncomfortable situation and to an attempt to loosen or cut these ties. But the large rich country which carries on only a small portion of its international economic relations with the country it dominates is normally preoccupied with its more vital other interests, for example, with its relations to other large powers" (Ibid.; Hirschman's emphasis)

In $A$ Dissenter's Confession, Hirschman (1984) suggests that attention asymmetries are inherent to sailing against the wind processes, because "[achieving progress in one important social objective] requires the utmost concentration of intellectual energies and political resources. The result is neglect of other crucial objectives"(Hirschman, 1984, p. 108). In the presence of antagonistic conflicts, at some point, pursuing a valuable end requires focusing the attention on the sequences of means that lead to this end, while ignoring the others. In his critique to the dependency thesis, however, Hirschman takes one step back, because he states that power asymmetries induce an asymmetrical valuation of ends; they even affect the possibility that ends are considered to be desirable. While for the powerful keeping a small country under control is just a minor end or even just a means for a more vital interest (for instance, augmenting its power vis à vis other powers), for the small country cutting the ties of dependency can be its most valued end. Moreover, in a context of antagonistic relations in which ends are perceived to be in conflict, the assessment of ends turns into an appraisal of the counterpart and its capacities. Therefore, whenever initial asymmetries are high, the powerful party tends to underestimate the capacity of its counterparts, which places the latter "in a favorable position to utilize what room of maneuver they have and may be able to widen this room" (Hirschman, 1978, p.48).

Nevertheless, this asymmetry of attention is not enough to explain why power asymmetries carry the seed of their own destruction, because it says nothing about the possibility of actually reverting the situation. In other words, asymmetrical valuations of the counterpart do not imply that the powerless parties will be effectively able to find appropriate means for avoiding the reaction of the powerful. After all, initial power asymmetries may endow the 
powerless party with weak means to pursue its ends, irrespective of the valuation of the powerful party, who can always count on strong means to attain its goals. However, Hirschman offers reasons to believe that reaction will be less effective in a situation of power asymmetries:

"From the point of view of Latin American aspirations, the advantage of day-to-day policy being in the hands of lower-level [U.S] diplomats heavily influenced by an intrusive business community is precisely that policies so formed are usually shortsighted as well as reasonably predictable.(...) For these reasons they are no match for a determinate adversary"(Hirschman, 1978, p. 48)

Besides, not only the subjective value of ends is inversely correlated to power asymmetries; this also holds for the objective appropriateness of means. Naturally, stronger means are chosen to attain more valuable ends, so it does not come as a surprise that the most capable diplomats are assigned to the most vital positions. However, Hirschman strengthens his argument by suggesting that policies towards Latin America are usually weak — shortsighted and reasonably predictableprecisely because low-level diplomats are heavily influenced by an intrusive business community. Surprisingly, this conclusion emerges from the triumph of the political project of modernity, for it was believed that the most important asset of a world ruled by interests was its "predictability"(Hirschman, 1977b, p. 49), because it implied "constancy" (Ibid., p.52), and hence easy governance (Hirschman, 2015[1986b], p. 202). Conversely, unpredictability was associated with power:

"Samuel Butler held that foolish and incapable persons in government 'have one advantage, above those that are wiser, and that of no mean importance; for no man can guess, nor imagine, beforehand, what course they will probably take in any business that occurs, when 'tis not uneasy to foresee, by their interests, what wiser men are like in reason to design" (Ibid., p. 50)

Therefore, somehow paradoxically, the heavy influence of a business community strongly interested on Latin American affairs made the United States less, and not more, powerful, because their actions became more predictable, hence easier to control. In this way, Hirschman turns on their back the theses that rely on asymmetric relations: in a sense, the presence of strong foreign interests on domestic affairs is not a source of powerlessness for the dependent party, but a source of maneuver.

To sum up, upon the absence of feudal shackles, the thesis of the development of underdevelopment and the dependency thesis were contrived to account for the political economy of development in Latin America. Notwithstanding their differences, in both cases the transfer of decision-making centers towards the outside is grounded on a logic of subordination that results from the early and uncontested victory of interests in the region. Nevertheless, 
building on his old economic concepts, Hirschman provides some mini-building blocks for an open political economics of development that allows for fragmentary conflicts and political counterforces.

\section{A passion for the possible}

In an effort for appropriating the discourse of development in an age of decline, thinkers in Latin America ventured into the political economy of development. While some of them blamed the persistence of feudal passions for the state of underdevelopment and ungovernability in the region, others took the opposite road, pointing to the uncontested victory of interests. While both ways offer new insights about the interactions between economics and politics in the problem of development, they prove to be self-defeating for their alleged purpose: achieving self-governed change. Moreover, Hirschman shows that these arguments are refuted by their own premises: the persistence of a traditional structure, the continuity in change, or structural bonds harbor counterforces that open new possibilities. Neither the failure, nor the uncontested victory of modernity entail absolute closures.

Furthermore, it may be misleading, or even utterly erroneous to speak about a complete failure or an uncontested victory of modernity; as Hirschman shows in the Passions and the Interests, from the onset, the political project of modernity was not unitary, but the result of unresolved conflicts. For instance, Hirschman argues that the doux commerce thesis had been contested by Adam Smith. In response to Steuart and Montesquieu, Smith considered that the decline of landowners resulted from their destructive passions, and not from the victory of their interests:

"they unwittingly relinquished their power as they attempted to take advantage of new opportunities for their consumption(...) In fact, the episode is better summarized as a victory of the passions (of cupidity and luxury) over the longer-run interest of the lords than as the taming of the passions by the interests"(Hirschman, 1977b, p. 102).

If the expansion of commerce was not enough for taming landowners in the XVIII ${ }^{\text {th }}$ century, the truncated penetration of capitalism in underdeveloped regions should not have been expected to do less. Perhaps the partial penetration of modern rationalities was more effective than expected: the destructive nature of passions will ultimately condemn their fate. This argument resembles the tale about agrarian reform in Colombia: landowners unwittingly relinquished their power because they fell prey of the destructiveness of their own passions. 
However, tame interests are not the only ones to blame for the failure of commerce to yield the political outcomes expected. As I showed in the previous chapter, when the doctrine of interests was struggling for preeminence, strong vested interests were associated with powerlessness, precisely for achieving what they were supposed to: predictability and easy government. According to Hirschman, Tocqueville took this argument one step forward, outlining that the doctrine of interests may have perverse effects on self-government, because it diverts attention from deciding autonomously about personal affairs:

"These people think they follow the doctrine of interest [Hirschman's emphasis], but they have only a crude idea of what it is, and to watch the better over what they call their business (leurs affaires), they neglect the principal part of it which is to remain their own masters [my emphasis]" (Ibid., 123)

Therefore, the conflict between the political arguments for and against capitalism before its triumph accounted for the possibility that either its defeat, or its triumph, could carry the seeds of their own destruction. Referring to the champions of dependency theory, Hirschman argues that "the failure to discover this countertendencies is not due only to difficulties of crossing interdisciplinary boundaries" —as I have shown that both attempts provided insightful interpretative openings-, but it "must be attributed to an intellectual orientation that is both undialectical and what I could call antipossibilist”(Hirschman, 1978, p. 49). The trademark of antipossibilist intellectuals is that they consider "beneath their scientific dignity to deal with possibility until after it has become actual and can then at least be redefined as probability" (Ibid.; Hirschman's emphasis). Even before dealing with the struggle between the passions and the interests in the XVIII ${ }^{\text {th }}$ century, Hirschman (1971) encouraged intellectuals to take stakes for a particular passion, the passion for the possible: "to widen the limits of what is or is perceived to be possible, be it at the cost of lowering our ability, real or imaginary, to discern the probable (...) what I shall call my possibilism"(p. 28).

According to Lepenies (2008), Hirschman's passion for embracing the possible, even at the expense of the probable, "can be perceived as his general underlying scientific method" (p. 440). Along the same line, McPherson (1986) describes Hirschman as a constructive skeptic, arguing that his propensity to reveal the hidden aspects and possibilities of phenomena, as opposed to finding general laws, is as close as we can get to his method. The possibilist scientist is characterized for mastering the art of trespassing, in two senses: trespassing disciplines, being "curious and sensitive to other perspectives", and cultures, in a "conscious effort of contextsensitivity" (Lepenies, 2008, p. 454,455). Additionally, possibilism is "solution oriented" and 
privileges "endogenous processes, over exogenous pushes" (Ibid., pp. 456,450). These characteristics explain why Hirschman's approach has been often related to pragmatism (Adelman, 2013; Santiso, 2000; Sanyal, 1994; Frobert et al., 2003).

Following the methodological interpretation of possibilism, Hirschman's passion for the possible offers openings for conducting scientific inquiry on development in a novel way ${ }^{17}$. In particular, the mini-building blocks of Hirschman's political economics of development exhibit the features of a possibilist science. For instance, the concern with the interactions between economics and politics and the emphasis on finding hidden rationalities in specific contexts are proof of his command of the art of trespassing, while the stress on the governmental advantages of sequential approaches, such as reform and linkages, is evidence of his pragmatic twist. In this way, the methodological interpretation seems to provide a clear understanding of the link between Hirschman's political economics and his possibilism. However, it is my claim that Hirschman's possibilism is more than a methodological stance: it is a statement about modern societies and the possibility of exerting change in the context of modernity. As I showed previously, the neglect of countertendencies is a trademark of the antipossibilist intellectual. For Hirschman, however, the search for countertendencies goes beyond a theoretical curiosity; he is interested in their consequences on political praxis:

"When I noted the phenomenon of economic forces alone leading to an imbalance or otherwise tension-laden or unsatisfactory state of affairs which needs to be corrected by political action, I have tried to locate specific 'agents of change' which, much like Marx's industrial proletariat, would have the motivation and power to bring about that action" (Hirschman, 1971, p. 20)

Identifying the features of the possibilist scientist is part of this effort to locate specific agents of change. Nevertheless, intellectual activity is by no means the only source of agency. The leader, who has the "ability to perceive change when most of one's contemporaries are still unable to do so" (Hirschman, 1971[1967b], p. 338) and exhibits an unusual "capacity to be surprised"(Hirschman, 1975, p. 397), is another example ${ }^{18}$. More generally, agents of change emerge from the very tensions of modernity, openly manifest in the problem of development:

\footnotetext{
${ }^{17}$ For instance, Ellerman (2004) and Easterly (2014) resort to Hirschman's writings to criticize the role of the expert in development, arguing for bottom-up approaches.

18 Inspired by Carlos Lleras Restrepo, Hirschman opposes the figure of the reform-monger to Weber's charismatic leader, "who holds to the average perceptions with an uncommon degree of 'passionate intensity' (...) and whose ability to empathize with them or his blindness to ongoing change may be an important part of his appeal"(Hirschman, 1971[1967], p. 338). Twenty years later, he will applaud the shift of Latin American policy-making "from ideological certainty to more open-ended, eclectic, skeptical inquiry"(Hirschman, 1986c,
} 
"At an earlier time, contempt for the countries designated as 'rude and barbarous' in the eighteenth century, as 'backward' in the nineteenth and as 'underdeveloped' in the twentieth had taken the form of relegating them to permanent lowly status (...). Given what was seen as their overwhelming problem of poverty, underdeveloped countries were expected to perform like wind-up toys and to 'lumber through the various stages of development single-mindedly (...). In sum, like the 'innocent' and doux trader of the eighteenth century, these countries were perceived to have only interests and no passions" (Hirschman, 2015[1982], p. 70)

I started the previous chapters by showing how the construct of the underdeveloped country was crucial for the emergence of development as a problem that deserved an independent field study. However, while analyzing the reasons for its decline, Hirschman denounces that, from the onset, this construct was relegated to a permanent lowly status; it was the contemporary manifestation of contemptuous expressions like 'rude and barbarous', and 'backward'. But new hopes on the triumph of capitalism in the $\operatorname{mid}-\mathrm{XX}^{\text {th }}$ century gave this contempt a definite form: underdeveloped countries were perceived to have only interests and no passions. Curiously enough, this was — in the smaller scale of individuals - a crucial argument for the triumph of capitalism in the XVIII ${ }^{\text {th }}$ century. In The Passions and the Interests, Hirschman argues that this statement made it possible to translate the language of passions into the language of interests, and therefore to provide an economic justification for capitalism:

"According to a long tradition, it was primarily the aristocracy that is animated by numerous noble or ignoble passions (...). The ordinary mortal was not thought to be so complicated. His principal concern was with subsistence and material improvement, generally as ends in themselves, and at best as proxies for the achievement of respect and admiration"(Hirschman, 1977b, pp. 111-112)

Following Hirschman's interpretation of the political project of modernity, when the governability of an aristocratic world was the main concern of modern thinkers, the core of the problem was the conflict between the passions and the interests. However, when the attention shifted to governing the ordinary mortal, the distinction between the passions and the interests became incomprehensible, because "either he had no passions or his passions could be satisfied through the pursuit of interests" (Ibid). This shift of attention - from the complex impassioned aristocrat, to the simple, plain ordinary man — ended with the "competing rationale" between the passions and the interests, and cleared the way for the already cited economic justification for capitalism: "general (material) welfare is best served by letting each member of society pursue his own (material) self-interest" (Ibid., p. 112). In the way, this harmonic view of capitalism

p. 32), which Santiso $(2000,2006)$ relates accordingly to a passion for the possible, or the search for open solutions beyond utopias. 
overshadowed the conflictive character of this political project, allowing economics to gain independence from politics: "while it was a splendid generalization, it represented a considerable narrowing of the field of inquiry over which social thought had ranged feely up to then and thus permitted intellectual specialization and professionalization” (Ibid.).

Two hundred years later, the development problem reproduced this argument on a global scale: the construct of the underdeveloped country became the $\mathrm{XX}^{\text {th }}$ century equivalent of the XVIII ${ }^{\text {th }}$ century innocent doux trader, who had only interests and no passions. However, for the ideologues of development in Latin America, it was not enough to provide an economic justification for the penetration of capitalism: they expected industrialization to yield selfgovernment, resorting to the political arguments for capitalism before its triumph. The perceived failure of this expectation in the early 1960s led to a reaction against the supposition that underdeveloped countries were going to perform like wind-up toys and to lumber through the various stages of development single-mindedly. In response, they tried to restore the conflict between the passions and the interests by delving into the political economy of development: Latin American societies turned out to be more complex than they were supposed to, either because they were still under the reign of destructive passions or because they were subordinated to alien interests.

However, this quest did not go far enough. Even if the feudal-shackles, the development of underdevelopment and the dependency theses constituted interpretative openings —as they provided valuable insights about the interactions between economics and politics-, they proved to be self-defeating for pursuing self-government. As I showed in the previous sections, the major pitfall of these theses did not lay on their scientific vices, but on their claims about modernity: while they rejected the assertion that underdeveloped countries were governed by self-interested subjects, they relinquished the possibility of finding impassionate individuals beyond the shackles of feudalism. Despite providing openings, their closed understanding of the modern man results in the neglect of possible agents of change.

In response to these closures, Hirschman tries to restore the conflict between the passions and the interests in its fullest expression, by providing a different claim about the modern man: "trying to reduce human action to a single motive — such as interest [is futile]", "for the only certain and predictable feature of human affairs is their unpredictability"(Hirschman, 2015[1986b], p. 211). Instead of following single-mindedly his self-interest, or being enslaved to destructive passions or alien interests, Hirschman's modern man is an open being endowed with a passion for the possible, eager of widening the limits of what is or is perceived to be possible, even at the 
expense of the probable. In consequence, modern civil societies are always equipped with "some unutilized problem-solving capacity"(Hirschman \& Lindblom, 1961, p. 79), that can be collectively exploited for contriving self-governed change, be it through centralized (reform) or decentralized learning processes (social conflicts). As it turns out, Hirschman's possibilism —as a claim about modernity- provides the foundations for an open political economics of development, in which "the inventiveness of history and a 'passion for the possible' are admitted as vital actors"(Hirschman, 1971, p. 37).

\section{Concluding remarks}

Hirschman was both a pioneer and a dissenter of high development theory. He shares with early theorists of development the virtues and misfortunes of committing himself to modernize the socalled underdeveloped world, but his late concern with the political dimensions of economic development gave new life to his early insights. While his main contribution to the literature on economic development was to instill the idea that idle resources and abilities were not obstacles, but assets that could be used by underdeveloped societies to overcome their relative backwardness, his political economics of development focused on the way that hidden rationalities, in general, could be exploited for contriving self-governed change. Once he realized that economic growth creates winners and losers, he acknowledged that unbalanced growth sequences might not progress smoothly; sailing against the wind was a better way of describing how societies move forward in the presence of antagonist conflicts. But not only his macroconcepts suffered from a political sublimation, Hirschman also became worried with the interactions between economics and politics in a smaller scale. Given that technological linkages are not always complementary, they may yield conflicts and diverse constellations of power. Not always wide-latitude activities are undesirable; they have a higher potential than narrow-latitude activities for creating powerful networks. Finally, while power asymmetries may yield absolute advantages in commerce, they may also divert attention from keeping the trading partner under control. Even if Hirschman can be appropriately considered a high-development theorist, his concepts survived to an age of decline by mutating into more amorphous and less easy to formalize, but less reductionist and more open insights. His new, transformed, concepts are the mini-building blocks for an unfinished —quoting Frobert and Ferranton (2003)_ political economics of development. 
However, that his research agenda remains open does not mean that it is awaiting for a closure, for it is closely entangled with Hirschman's broader commitment to an open society. Hirschman's political economics of development should not be seen exclusively through a methodological lens; it is grounded on his possibilism, or as I have argued, on a claim about modernity and the possibility of change in this context. His close acquaintance with Latin Americans, their historical pursuits and contemporary concerns, molded his understanding of development in terms of self-governance. After all, beyond any single standard of development, decision-making processes in civic societies inevitably involve the task of self-discovery and selfaffirmation. But if this is the purpose of theorizing about the interaction between economics and politics, an open notion of development cannot be grounded on contemptuous claims about modern societies and their inability to deliberate collectively beyond the logic of interests. Perhaps, "more civilized political circumstances necessarily imply a less transparent and less predictable society" (Hirschman, 2015[1986b], p. 211). The claim that modern societies will remain unfinished as long as the modern man is allowed to follow the passion for widening the limits of the possible is Hirschman's main contribution to contemporary debates about development and modernity, and the main reason for revisiting his work today.

\section{Bibliography}

Acemoglu, D., \& Robinson, J. A. (2006). De Facto Political Power and Institutional Persistence. Political Economy, 96(2), 325-330.

Adelman, J. (2013). Worldly Philosopher: The Odyssey of Albert O. Hirschman. Princeton: Princeton University Press.

Alacevich, M. (2016). Albert O. Hirschman and the Rise and Decline of Development Economics. In L. Fiorito, S. Scheall, \& C. E. Suprinyak (Eds.), Research in the History of Economic Thought and Mehodology-Including a Symposium on Albert O. Hirschman (pp. 13-39). Emerald Group Publishing Limited.

Baran, P. (1952). On the Political Economy of Backwardness. The Manchester School of Economy and Social Studies, 20(1), 66-84.

Bardahn, P. (1993). Economics of Development and the Development of Economics. Journal of Economic Perspectives, 7(2), 129-142.

Bianchi, A. M. (2007). Albert Hirschman na América Latina e sua trilogia sobre desenvolvimiento economico. Economia e Sociedade, 16(2(30)), 131-150. 
Cardoso, F. H., \& Faletto, E. (1969). Dependencia y desarrollo en América Latina. México D.F: Siglo XXI Editores.

Chonchol, J. (1965). Land Tenure and Development in Latin America. In C. Veliz (Ed.), Obstacles to Change in Latin America (pp. 75-90). London: Oxford University Press.

Cot, A. (2010). Albert O. Hirschman: An Intellectual Maverick. La Revue Tocqueville, 41(2), 62-79.

Easterly, W. (2014). The Tyranny of Experts: Economists, Dictators, and the Forgotten Rights of the Poor. Basic Books.

Ellerman, D. (2004). Revisiting Hirschman on Development Assistance and Unbalanced Growth. Eastern Economic Journal, 30(2), 311-331.

Escobar, A. (1995). Encountering Development: The Making and Unmaking of the Third World. Princeton: Princeton University Press.

Evans, P. (1986). Generalized Linkage in Industrial Development: A Reexamination of Basic Petrochemicals in Brazil. In A. Foxley, M. S. McPherson, \& G. O’Donnell (Eds.), Development, Democracy, and the Art of Trespassing: Essays in Honor of Albert O. Hirschman (pp. 7-27). Notre Dame: University of Notre Dame Press.

Foxley, A., McPherson, M. S., \& O’Donnell, G. (Eds.). (1986). Development, Democracy, and the Art of Trespassing: Essays in honor of Albert O. Hirschman. Notre Dame: University of Notre Dame Press.

Frobert, L., \& Ferranton, C. (2003). L'Enquête inachevée: intrdoduction à l'économie politique d'Albert O. Hirschman. Presses universitaires de France.

Furtado, C. (1965). Political Obstacles to the Economic Development of Brazil. In C. Veliz (Ed.), Obstacles to Change in Latin America (pp. 145-162). Oxford University Press.

Gerschenkron, A. (1962). Economic Backwardness in Historical Perspective: A Book of Essays. Cambridge, Ma: Belknap Press of Harvard University Press.

Gualerzi, D., \& Sunna, C. (2016). Introduction: The Rise and Decline of Development Economics in the History of Economic Thought. In D. Gualerzi \& C. Sunna (Eds.), Development Economics in the Twenty-First Century. New York: Routledge.

Gunder-Frank, A. (1967). Capitalism and Underdevelopment in Latin America: Historical Studies of Chile and Brazil. New York: Monthly Review Press.

Hirschman, A. O. (1945). National Power and the Structure of Foreign Trade. Berkeley: University of California Press.

- (1958a). Economic Development: Current Research and Problem Areas. 
- (1958b). The Strategy of Economic Development. New Haven: Yale University Press.

— (1971[1961a]). Critical Comments on Foreign Aid Strategies. In A Bias for Hope: Essays on Development and Latin America. New Haven: Yale University Press.

— (1971[1961b]). Ideologies of Economic Development in Latin America. In A Bias for Hope: Essays on Development and Latin America (pp. 270-311). New Haven: Yale University Press.

— (1963). Journeys Towards Progress. New York: The Twentieth Century Fund, Inc.

- (1971[1965a]). Obstacles to Development: A Classification and Quasi-Vanishing Act. In $A$ Bias for Hope: Essays on Development and Latin America1 (pp. 312-327). New Haven: Yale University Press.

- (2015[1965b]). The Political Economy of Import-Substituting Industrialization in Latin America. In J. Adelman (Ed.), The Essential Hirschman (pp. 102-136). Princeton: Princeton University Press.

— (1967a). Development Projects Observed. Washington: The Brookings Institution.

- (1971[1967b]). Underdevelopment, Obstacles to the Perception of Change, and Leadership. In A Bias for Hope: Essays on Development and Latin America (pp. 328-341). New Haven: Yale University Press.

- (1971). Political Economics and Possibilism. In A Bias for Hope: Essays on Development and Latin America (pp. 1-37). New Haven: Yale University Press.

- (1975). Policymaking and Policy Analysis in Latin America-A Return Journey. Policy Sciences, 6, 385-402.

- (1984[1976]). Hegel, el imperialismo y el estancamiento estructural. In De la economía a la politica y más allá (pp. 213-224). México D.F: Fondo de Cultura Económica.

- (2015[1977a]). A Generalized Linkage Approach to Development, With Special Reference to Staples. In J. Adelman (Ed.), The Essential Hirschman (pp. 155-194). Princeton: Princeton University Press.

- (1977b). The Passions and the Interests. Princeton: Princeton University Press.

- (1978). Beyond Asymmetry: critical notes on myself as a young man and some other old friends. International Organization, 32(1), 45-50.

- (1979). The Turn to Authoritarianism in Latin America and the Search for its Economic Determinants. In D. Collier (Ed.), The New Authoritarianism in Latin America (pp. 61-98). Princeton: Princeton University Press. 
- (2015[1982a]). Rival Views on Market Society. In J. Adelman (Ed.), The Essential Hirschman (pp. 214-247). Princeton: Princeton University Press.

— (2015[1982b]). The Rise and Decline of Development Economics. In J. Adelman (Ed.), The Essential Hirschman (pp. 49-73). Princeton: Princeton University Press.

- (1984). A Dissenter's Confession: “The Strategy of Economic Developent” Revisited. In G. M. Meier \& D. Seers (Eds.), Pioneers in Development (pp. 87-111). The World Bank.

- (1989[1986a]). Los eslabonamientos en el desarrollo económico. In Enfoques alternativos sobre la sociedad de mercado (pp. 60-79). México D.F: Fondo de Cultura Económica.

— (2015[1986b]). The Concept of Interest: from Euphemism to Tautology. In J. Adelman (Ed.), The Essential Hirschman (pp. 195-213). Princeton: Princeton University Press.

- (1986c). The Political Economy of Latin American Development: Seven Exercises in Retrospection.

- (1994a). A Propensity to Self-Subversion. In L. Reynolds \& D. A. Schön (Eds.), Retbinking the Development Experience: Essays provoked by the work of Albert O. Hirschman (pp. 277-282). Brookings Institution and The Lincoln Institute of Policy Land.

— (1994b). Social Conflicts as Pillars of Democratic Market Society. Political Theory, 22(2), 203218.

— (1997). La Morale Secrète de l'Économiste. Paris: Les Belles Lettres.

Hirschman, A. O., \& Lindblom, C. E. (1971[1961]). Economic Development, R \& D, And Policy Making. In A Bias for Hope: Essays on Development and Latin America (pp. 63-84). New Haven: Yale University Press.

Krugman, P. (1993). Towards a Counter-Counterrevolution in Development Theory. In Proceedings of the World Bank. Annual Conference on Development Economics 1992 (pp. 15-62). Washington: The International Bank for Reconstruction and Development.

- (1994). The Fall and Rise of Development Economics. In L. Rodwin \& D. A. Schön (Eds.), Rethinking the Development Experience: Essays provoked by the work of Albert O. Hirschman1 (pp. 39-58). The Brookings Institution and The Lincoln Institute of Land Policy.

Lepenies, P. H. (2008). Possibilism: An Approach to Problem Solving Derived from the Life and Work of Albert O. Hirschman. Development and Change, 39(3), 437-459.

Little, I. M. D. (1982). Economic Development: Theory, Policy, and International Relations. New York: The Twentieth Century Fund, Inc.

Maluf, R. (2015). Hirschman e a dessacralização do desenvolvimento por um desenvolvimentista. Revista de Economia Política, 35(1), 43-63. 
McPherson, M. S. (1986). The Social Scientist as Constructive Skeptic: On Hirschman's Role. In A. Foxley, M. S. McPherson, \& G. O'Donnell (Eds.), Development, Democracy, and the Art of Trespassing: Essays in Honor of Albert O. Hirschman (pp. 305-313). Notre Dame: Notre Dame University Press.

Ocampo, J. A. (2008). Hirschman, la industrialización y la teoría del desarrollo. Desarollo Y Sociedad, 62, 41-65.

Özçelik, E. (2014). Albert O. Hirschman: A "Beamish" Social Scientist for Our Grandchildren. Development and Change, 45(5), 1111-1133.

Pinto, A. (1965). Political Aspects of Economic Development in Latin America. In C. Veliz (Ed.), Obstacles to Change in Latin America (pp. 9-46). London: Oxford University Press.

Prebisch, R. (1949). El desarrollo económico de la América Latina y algunos de sus principales problemas. Santiago: CEPAL.

Rodrik, D. (2007). One Economics, Many Recipes: What We Have Learned Since Albert Hirschman. Items and Issues, 6(1), 1-8.

Rodwin, Ll., \& Schön, D. A. (Eds.). (1994). Retbinking the Development Experience: Essays Provoked by the Work of Albert O. Hirschman. Washington: The Brookings Institution and The Lincoln Institute of Land Policy.

Santiso, J. (2000). Hirschman's view of development, or the art of trespassing and selfsubvertion. Cepal Review, 70, 93-109.

- (2006). Latin America's Political Economy of the Possible: Beyond Good Revolutionaries and FreeMarketers. Cambridge: MIT Press.

Schön, D. A. (1994). Hirschman's Elusive Theory of Learning. In Retbinking the Development Experience: Essays provoked by the work of Albert O. Hirschman.

Sen, A. (1983). Development: Which Way Now? The Economic Journal, 93(372), 745-762.

- (1988). The Concept Of Development. In H. Chenery \& T. N. Srinivasan (Eds.), Handbook of Development Economics (pp. 10-26). Elsevier Science Publishers B.V.

- (2000). Development as Freedom. New York: Anchor Books.

Simon, H. A. (1955). A Behavioural Model of Rational Choice. The Quarterly Journal of Economics, 69(1), 99-118.

Streeten, P. P. (1984). Comment. In 1Pioneers in Development (pp. 115-118). Washington: A World Bank Publication. 
Sunkel, O. (1965). Change and Frustration in Chile. In C. Veliz (Ed.), Obstacles to Change in Latin America (pp. 116-145). London: Oxford University Press.

Sunkel, O., \& Paz, P. (1970). El subdesarrollo latinoamericano y la teoría del desarrollo. México D.F: Siglo XXI Editores.

Taylor, L. (1994). Hirschman's Strategy at Thirty-Five. In L. Rodwin \& D. A. Schön (Eds.), Rethinking the Development Experience: Essays provoked by the work of Albert O. Hirschman1 (pp. 59-66). The Brookings Institution and The Lincoln Institute of Land Policy.

Teitel, S. (Ed.). (1991). Towards a New Development Strategy for Latin America: Pathways from Hirschman's Thought. Washington: Inter-American Development Bank.

Veliz, C. (1965). Introduction. In C. Veliz (Ed.), Obstacles to Change in Latin America (pp. 1-8). London: Oxford University Press.

Watkins, M. H. (1963). A Staple Theory of Economic Growth. The Canadian Journal of Economics and Political Science / Revue canadienned'Economique et de Science Politique, 29(2), 141-158. 